ERC Working Papers in Economics 18/07

April / 2018

\title{
GROSS CAPITAL INFLOWS AND OUTFLOWS: TWINS OR DISTANT COUSINS?
}

\author{
Erdal Özmen \\ Department of Economics, Middle East Technical University, Ankara, Turkey \\ E-mail: ozmen@metu.edu.tr
}

Fatma Taşdemir

Department of Economics, Middle East Technical University, Ankara, Turkey

E-mail: tfatma@metu.edu.tr 


\title{
GROSS CAPITAL INFLOWS AND OUTFLOWS: TWINS OR DISTANT COUSINS?
}

\author{
Erdal Özmen \\ Middle East Technical University, Department of Economics, Ankara, Turkey \\ E-mail: ozmen@metu.edu.tr \\ and \\ Fatma Taşdemir \\ Middle East Technical University, Department of Economics, Ankara, Turkey \\ E-mail: tfatma@metu.edu.tr
}

\begin{abstract}
We investigate the long-run relations and equilibrium correction mechanisms between gross capital inflows, outflows and global financial conditions for advanced and emerging market economies. According to our results, the findings of the recent empirical literature, suggesting that twin behaviour of capital inflows and outflows resulting from domestic and foreign investors to behave as distant cousins tend to be the case for the long-run. The short-run relations, however, often appear to be consistent with the conventional theory suggesting that the behaviours of residents and non-residents do not systematically diverge from each other. Consistent with the flight to safety concerns, capital outflows from EME and capital inflows to $\mathrm{AE}$ tend to increase in the long-run in response to worsening global financial conditions. We find that, these results essentially hold also for the main components of capital flows.
\end{abstract}

Keywords: Advanced economies, Cointegration, Emerging market economies, Equilibrium correction, Foreign direct investments, Gross capital flows, Portfolio flows.

JEL Codes: F21, F30, F32, G01 


\section{INTRODUCTION}

International capital flows and global financial conditions are often found as one of the most important determinants of growth (Kose et al., 2012) and business cycles (Erdem and Özmen, 2015) in emerging market (EME) and advanced (AE) economies. The recent studies often find that, monetary policies of financially integrated $\mathrm{EME}$ and $\mathrm{AE}$ crucially depend on the changes in global financial conditions and interest rates even under flexible exchange rate regimes (Rey, 2015). Consequently, understanding the basic determinants of capital flows has always been a topical research topic in open economy macroeconomics.

There is a wide and growing literature on the determinants of capital flows (see, e.g., Montiel, 2014; Avdjiev, et al., 2017). Gross capital flows, compared to net capital flows, are often found to be much larger and more volatile and thus crucially important for growth and financial stability (Milesi-Ferretti and Tille, 2011; Broner, et al., 2013 and Davis and van Wincoop, 2017). The recent literature suggests a potentially puzzling result that gross capital inflows (net purchases of domestic assets by foreign residents) and outflows (net purchases of foreign assets by domestic residents) tend to move together (Broner, et al., 2013 and Davis and van Wincoop, 2017). In this sense, capital inflows and outflows are twins.

Under perfect financial markets with no asymmetric information, frictions and home bias, the portfolio choices of residents and non-residents may be expected not to systematically diverge from each other especially in the long-run. Consequently, capital inflows and outflows may be expected to be negatively correlated. The recent literature, on the other hand, often finds that, this is not the case for gross capital inflows and outflows. Broner et al., (2013), for instance, finds that when foreigners invest in a country, domestic agents invest abroad, and vice versa. Barrot and Serven (2018) also finds that capital inflows and outflows are highly correlated. In the same vein, the results by Avdjiev et al., (2017) "imply that foreign and domestic investors behave differently in response to domestic and global shocks" (p.8), and this is "inconsistent with standard international macroeconomic models, which treat domestic and foreign investors symmetrically" (p.1). 
The presence of asymmetric information (Tille and van Wincoop, 2014) or exchange rate risk (Broner et al., 2013), both leading to differences in expected returns, are amongst the basic explanations of the co-movement of capital inflows and outflows. Milesi-Ferreti and Tille (2011) suggests relative perceived riskiness of home and foreign assets and the consequent differential shocks to risk aversion as an another source of asymmetry. Relative expected deterioration of property rights of non-residents leading them to have an incentive to sell domestic assets in the case of a financial turbulence may also lead to an asymmetry according to Broner, Martin, and Ventura (2010). According to Tille and van Wincoop (2010), on the other hand, the portfolio growth component of capital flows can generate positive correlation between capital inflows and outflows when saving rates move together across countries. Davis and van Wincoop (2017) provides a theoretical model and an empirical support for their postulation that higher international financial integration leads to co-movement of capital inflows and outflows. Accordingly, financial globalization causes higher volatility of gross flows relative to net flows and consequently increases the correlation, while trade globalization does the opposite.

This paper investigates the long-run relationships and equilibrium correction mechanisms between gross capital inflows and outflows for a relatively large number of emerging market (EME) and advanced (AE) economies. The co-movement of capital inflows and outflows may also be driven by a common factor such as global financial cycle. Consequently, following the recent literature, including Rey (2016), Forbes and Warnock (2012), Bruno and Shin (2015) and Barrot and Serven (2018), we also consider the role of international financial conditions on the evolution of capital flows. The recent literature, including Blanchard et al., (2017), shows also the importance of the main components of capital flows along with the aggregate gross flows. Consequently, we consider not only aggregate gross flows but also their main components: portfolio (bond and equity), foreign direct investment and other investment (mainly bank intermediated) flows. 
The bulk of the literature does not take into account the integration and cointegration properties of the variables in empirically investigating the relationship between capital inflows and outflows and thus may be subject to problems of spurious regression along with estimating equations containing variables with different orders of integration. Such an approach often does not allow to make a distinction between long-run and short-run relations and the adjustment mechanisms towards long-run equilibrium. Furthermore, the literature often employs the conventional panel fixed effects procedure which may be subject to an endogeneity problem under an invalid conditioning about the long-run drivers of capital flows. To tackle these issues, we employ Johansen-Fisher cointegration procedure based on a reparametrized panel vector autoregression model which allows us to estimate the long-run relationships and equilibrium correction mechanisms along with to test the validity of weak exogeneity restrictions.

The plan for the rest of the paper is as follows. Section II presents our empirical results by using annual data for a panel of relatively large number of EME and AE. In Section II.1, we consider the EME sample. Section II.2 presents the results for the AE sample. Finally, Section III concludes.

\section{GROSS CAPITAL INFLOWS AND OUTFLOWS: EMPIRICAL RESULTS}

We consider gross capital flows for an unbalanced panel of 33 emerging market $^{1}$ (EME) and 21 advanced $^{2}$ (AE) economies over the annual sample from 1986 to 2015 . The choice of the sample is basically determined by data availability ${ }^{3}$.

Figures 1 and 2, respectively, present the evolution of aggregate gross capital flows $^{4}$ (scaled by GDP in current US dollars) for samples of EME and AE. Both of

1 Emerging market economies are those that are included in the Morgan Stanley Capital International (MSCI) index, and comprises Argentina, Brazil, Bulgaria, Chile, China, Colombia, Croatia, Czech R., Egypt, Estonia, Hungary, India, Indonesia, Israel, Kazakhstan, Kenya, Lithuania, Mexico, Morocco, Nigeria, Pakistan, Peru, Philippines, Poland, Romania, Russian F., S. Africa, Serbia, Slovak R., Slovenia, S. Korea, Thailand, Turkey.

2 The AE sample includes Australia, Austria, Belgium, Canada, Denmark, Finland, France, Germany, Greece, Italy, Japan, Netherlands, New Zealand, Norway, Portugal, Singapore, Spain, Sweden, Switzerland, UK, USA.

${ }^{3}$ The VIX data are from Chicago Boards Options Exchange website. The VIX data are available only after 1986 . Therefore, the estimation sample is 1986-2015. 
the figures show a strong co-movement between capital inflows and outflows. The positive correlation appears to be much higher for AE. Net capital inflows (gross capital inflows minus gross capital outflows) is positive for almost the whole sample period for the EME. The absolute magnitude of the net capital inflows (and thus current account imbalances) tends to be much smaller in AE than EME.

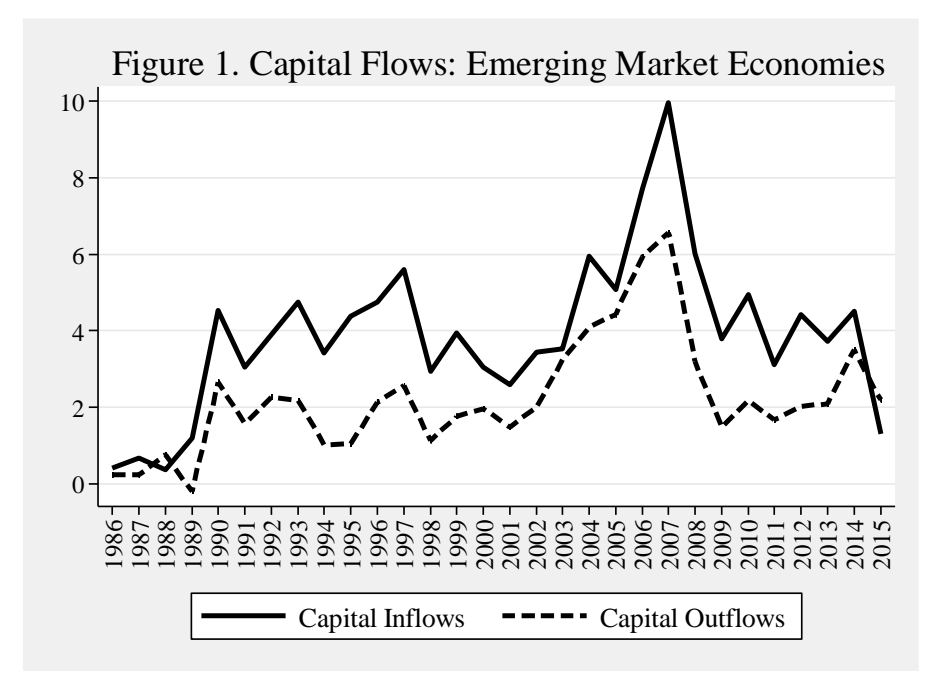

Figure 2. Capital Flows: Advanced Economies

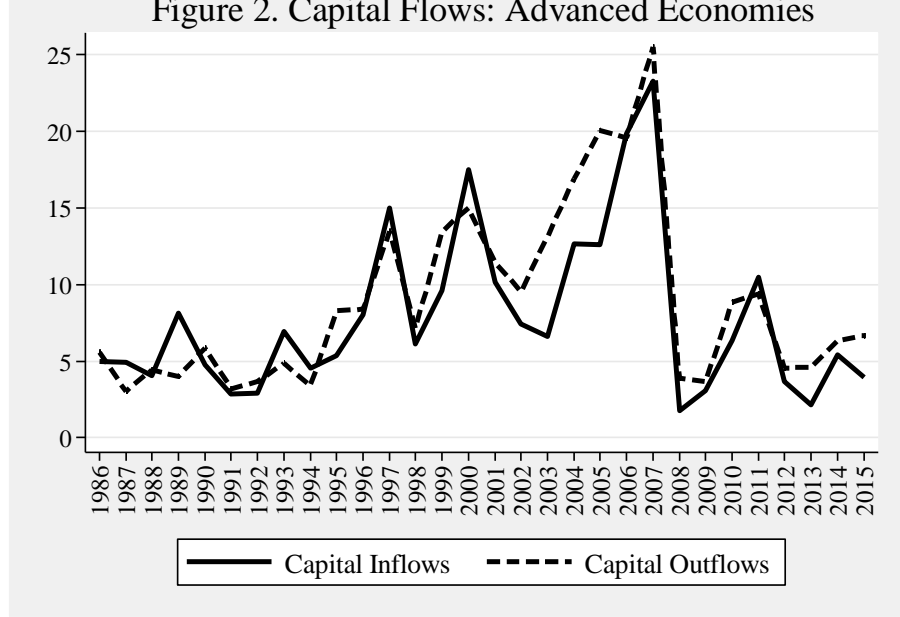

${ }^{4}$ All the capital flows data, measured in US dollars, are from International Financial Statistics of the International Monetary Fund (IMF). Following the IMF's Balance of Payments Statistics Yearbooks, capital inflows and outflows, respectively, are defined as net purchases of domestic assets by foreign residents and net purchases of foreign assets by domestic residents. The real GDP (current US dollars) data are from World Bank World Development Indicators. 
A useful starting point to investigate the long-run relationships between gross capital inflows and outflows is the following benchmark equations:

$$
\begin{aligned}
& \mathrm{COF}_{\text {it }}=\mathrm{b}_{0}+\mathrm{b}_{1} \mathrm{CIF}_{\mathrm{it}}+\mathrm{b}_{2} \mathrm{vix}_{\mathrm{t}}+\mathrm{u} 1_{\mathrm{it}} \\
& \mathrm{CIF}_{\mathrm{it}}=\mathrm{a}_{0}+\mathrm{a}_{1} \mathrm{COF}_{\mathrm{it}}+\mathrm{a}_{2} \mathrm{vix}_{\mathrm{t}}+\mathrm{u} 2_{\mathrm{it}}
\end{aligned}
$$

In the equations, CIF and COF are, respectively, gross capital inflows and outflows scaled by GDP in current US dollars and vix is the log of the Chicago Board Options Exchange's equity option volatility index (VIX). Following Broner et al., (2013), we define the equations both for CIF and COF. VIX is often used as a proxy for global liquidity conditions (Gonzales-Rozada and Levy-Yeyati, 2008; Özatay et al., 2009) and the state of the financial cycle (Rey, 2015, 2016 and Obstfeld et al., 2017). A decrease in VIX is associated with a greater risk-appetite or better global financial conditions. In accord with the financial cycle postulation, global financial conditions are expected to be amongst the important determinants of international capital flows (Forbes and Warnock, 2012; Bruno and Shin, 2015; Barrot and Serven, 2018).

Table 1 reports the results of Levin, et al., (2002) panel unit root tests for the capital flow variables along with augmented Dickey-Fuller tests for vix . The results $^{5}$ suggest that all these variables are integrated of order 1 (I(1)). Given that CIF, COF and vix are cointegrated we can define a panel equilibrium correction mechanism (PECM) representation which allows us to assess the adjustment mechanisms to deviations from the long-run equilibrium relationship along with the short-run dynamics. For this, we consider the following reparametrized $\mathrm{p}^{\text {th }}$ order panel vector autoregression $(\operatorname{PVAR}(\mathrm{p}))$ process:

$$
\Delta \mathrm{Y}_{\mathrm{it}}=\mathrm{c}_{0}+\alpha_{1} \mathrm{EC}_{\mathrm{it}-1}+\Gamma_{1} \Delta \mathrm{Y}_{\mathrm{it}-1}+\ldots+\Gamma_{\mathrm{p}-1} \Delta \mathrm{Y}_{\mathrm{it}-\mathrm{p}-1}+\mathrm{u}_{\mathrm{it}}
$$

where $\mathrm{Y}$ is a vector of non-stationary $\mathrm{I}(1)$ variables, $\Delta$ is the first difference operator and EC (equilibrium correction term) are the stationary deviations from the long-run equilibrium. Johansen (1995) provides a maximum likelihood procedure to estimate and test the cointegrating vectors along with ECM mechanisms for VAR processes.

\footnotetext{
5 The unit root tests for the subsamples of countries yielded essentially the same results and not reported to save the space.
} 
Following Fisher (1932), Maddala and Kim (1998) proposes to combine the p-values of the individual Johansen statistics for each cross-sectional unit to obtain a test statistics for the full panel ${ }^{6}$.

\begin{tabular}{|c|c|c|}
\hline \multicolumn{3}{|c|}{ Table 1. Unit Root Tests } \\
\hline & Levels & First Differences \\
\hline Variables & \multicolumn{2}{|c|}{$L L C$} \\
\hline c_of & 0.16 & $-21.5^{* *}$ \\
\hline c_ifit & -0.53 & $-32.3 * *$ \\
\hline p_of ${ }_{\text {it }}$ & -0.52 & $-13.0 * *$ \\
\hline p_if ${ }_{i t}$ & 0.95 & $-23.7 * *$ \\
\hline$\Delta \mathrm{fdi}_{\mathrm{O}} \mathrm{f}_{\mathrm{it}}$ & -0.94 & $-48.4 * *$ \\
\hline$\Delta$ fdi_ifit & -0.05 & $-47.1 * *$ \\
\hline$\Delta$ oinv_of ${ }_{\text {it }}$ & -0.95 & $-37.4 * *$ \\
\hline$\Delta$ oinv_if $f_{i t}$ & -0.73 & $-41.7 * *$ \\
\hline Variable & \multicolumn{2}{|c|}{$A D F$} \\
\hline $\operatorname{vix}_{t}$ & -0.37 & $-4.09 * *$ \\
\hline \multicolumn{3}{|c|}{$\begin{array}{l}\text { LLC and ADF are the Levin, et al., (2002) panel unit root and } \\
\text { augmented Dickey-Fuller tests, respectively. ** denotes the } \\
\text { rejection of the unit root null at the } 5 \% \text { level. The unit root test } \\
\text { equations contain also a constant term and the augmentation lag } \\
\text { length is chosen as } 2 \text { which may be plausible for annul data. }\end{array}$} \\
\hline
\end{tabular}

${ }^{6}$ In a similar vein, Larsson, Lyhagen and Lothgren (2001) suggests using the average of the Johansen trace statistics. Groen and Kleibergen (2003) shows that the limiting distributions of likelihood ratio (LR) statistics to test for a common cointegrating rank for panels can be represented as a sum of the individual Johansen trace statistics for cross-sections. Örsal and Droge (2014) proposes to standardize the average of the individual LR trace statistics over the crosssections. 


\section{II.1. The Dynamics of Capital Outflows from EME}

To estimate the panel ECM (PECM) representation for a PVAR(2) proces for the variable space containing $\mathrm{COF}, \mathrm{CIF}$ and vix, which allows us to assess adjustment mechanisms to a deviation from the long-run equilibrium relationship along with the short run dynamics, we first consider the following specification:

$\Delta \mathrm{COF}_{\mathrm{it}}=\mathrm{c}_{0}+\alpha_{1} \mathrm{EC}_{\mathrm{it}-1}+\Gamma_{1} \Delta \mathrm{COF}_{\mathrm{it}-1}+\Gamma_{2} \Delta \mathrm{CIF}_{\mathrm{it}-1}+\Gamma_{3} \Delta \mathrm{vix}_{\mathrm{t}-1}+\mathrm{u}_{\mathrm{it}}$

In (4), given that COF, CIF and vix are cointegrated, $\alpha_{1}$ represents the speed of adjustment to deviations from the long-run relationship ${ }^{7} \mathrm{EC}_{\mathrm{it}-1}$, where $\mathrm{EC}$ is $\left(\mathrm{COF}_{\mathrm{it}}\right.$ $-\mathrm{b}_{1} \mathrm{CIF}_{\text {it }}-\mathrm{b}_{2} \mathrm{vix}_{\mathrm{t}}$ ). VIX proxies global financial conditions (GFC). A decrease in VIX is associated with better GFC.

Table 2 presents the PECM results for capital outflows and their main components for the EME sample. The results of the Johansen-Fisher trace statistics $(\lambda(r))$ strongly suggest the presence of a single cointegration vector for the variable spaces containing capital outflows, inflows and vix at the $1 \%$ level. According to the results by equation (2.1), there is a positive relationship between aggregate capital outflows (c_of) and inflows (c_if) in the long-run. This is consistent with the earlier findings by Broner et al., (2013), suggesting that when foreign capital leaves, residents repatriate their capital generating a retrenchment in net capital flows. An increase in VIX (a decrease in the risk appetite in global financial markets leading to worsening global liquidity conditions) leads to an increase in capital outflows in the long-run. The magnitude of the estimated EC coefficient suggests that the speed of adjustment of capital outflows to deviations from co-integration is relatively fast. During periods of financial turbulence, residents tend to substantially decrease their net purchases of foreign assets in the short-run as suggested by the negative coefficient. The co-movement of aggregate capital outflows and inflows, however,

\footnotetext{
${ }^{7}$ Our preliminary analysis suggested that, capital outflows, not the inflows, are often the adjusting variables to deviations from long-run equilibrium relationships for the EME sample. The EC coefficients for the PECM specifications for aggregate, portfolio, FDI and other investment inflows are estimated, respectively, as 0.021(0.020), -0.477(0.043)**, 0.017(0.013), -0.013(0.07), with standard errors in parentheses and $* *$ denote statistical significance at the $1 \%$ level .
} 
appears not to be the case in the short-run for the EME sample. Accordingly, consistent with the conventional wisdom, the behaviours of domestic and foreign residents tend to substantially not diverge from each other in the short-run.

\begin{tabular}{|c|c|c|c|c|}
\hline $\begin{array}{l}\text { Dependent } \\
\text { variable }\end{array}$ & $\Delta c \_o f_{i t}$ & $\Delta$ p_of ${ }_{\text {it }}$ & $\Delta$ fdi_of ${ }_{\text {it }}$ & $\Delta$ oinv_of ${ }_{\text {it }}$ \\
\hline $\begin{array}{l}\text { Capital flows } \\
\text { variable }\end{array}$ & $\begin{array}{l}\text { Aggregate } \\
\text { Capital } \\
\text { outflows }\end{array}$ & $\begin{array}{l}\text { Portfolio } \\
\text { outflows }\end{array}$ & FDI outflows & $\begin{array}{l}\text { Other inv. } \\
\text { outflows }\end{array}$ \\
\hline Equation & $(2.1)$ & $(2.2)$ & $(2.3)$ & $(2.4)$ \\
\hline \multicolumn{5}{|c|}{ Long-run (EC) } \\
\hline & c_of it $_{1}$ & p_of & fdi_of ${ }_{\text {it }}$ & oinv_of ${ }_{\text {it }}$ \\
\hline$i f_{i t}$ & $0.402(0.043)^{* *}$ & $1.226(0.099)^{* *}$ & $0.287(0.042)^{* * *}$ & $-0.100(0.037)^{* *}$ \\
\hline$v^{2} x_{t}$ & $0.307(0.096)^{* *}$ & \begin{tabular}{|l}
$-0.096(0.055)$ \\
\end{tabular} & \begin{tabular}{|l|}
$0.026(0.048)$ \\
\end{tabular} & $0.386(0.044)^{* *}$ \\
\hline \multicolumn{5}{|c|}{ Short-run dynamics } \\
\hline $\mathrm{EC}_{\mathrm{t}-1}$ & $-0.681(0.046)^{* *}$ & $-0.326(0.035)^{* *}$ & $-0.716(0.034)^{* *}$ & $-0.566(0.040)^{* *}$ \\
\hline$\Delta \mathrm{of}_{\mathrm{it}-1}$ & $0.053(0.041)$ & $-0.269(0.038)^{* *}$ & $0.384(0.033)^{* *}$ & $-0.125(0.037)^{* *}$ \\
\hline$\Delta \mathrm{if}_{\mathrm{it}-1}$ & $-0.083(0.035)^{* *}$ & $-0.234(0.040)^{* *}$ & $-0.093(0.026)^{* *}$ & $0.017(0.020)$ \\
\hline$\Delta \mathrm{vix}_{\mathrm{t}-1}$ & $-2.736(0.601)^{* *}$ & $-0.503(0.305)$ & $-0.464(0.301)^{*}$ & $-0.955(0.297)^{* *}$ \\
\hline Statistics & $\begin{array}{l}\mathrm{N}=33 \quad \mathrm{NT}=677 \\
\mathrm{R}^{2}=0.31 \\
\mathrm{~F}=101.7 \\
\lambda(0)=187.1^{\dagger \dagger} \\
\lambda(1)=59.8 \\
\lambda(2)=30.6\end{array}$ & $\begin{array}{l}\mathrm{N}=33 \quad \mathrm{NT}=644 \\
\mathrm{R}^{2}=0.28 \\
\mathrm{~F}=82.5 \\
\lambda(0)=234.4^{\dagger \dagger} \\
\lambda(1)=67.3 \\
\lambda(2)=42.1\end{array}$ & $\begin{array}{l}\mathrm{N}=33 \quad \mathrm{NT}=786 \\
\mathrm{R}^{2}=0.37 \\
\mathrm{~F}=153.4 \\
\lambda(0)=158.0^{\dagger \dagger} \\
\lambda(1)=37.4 \\
\lambda(2)=28.9\end{array}$ & $\begin{array}{l}\mathrm{N}=33 \mathrm{NT}=798 \\
\mathrm{R}^{2}=0.33 \\
\mathrm{~F}=132.5 \\
\lambda(0)=162.2^{\dagger \dagger} \\
\lambda(1)=64.0 \\
\lambda(2)=29.4\end{array}$ \\
\hline \multicolumn{5}{|c|}{$\begin{array}{l}\text { Notes: The values in parentheses are the standard errors. } * \text { and } * *, \text { respectively, denote significance } \\
\text { at } 5 \% \text { and } 1 \% \text { levels. } \mathrm{N} \text { and NT are, correspondingly, the numbers of countries and effective } \\
\text { number of observations. } \lambda(\mathrm{r}) \text { are the Johansen-Fisher trace statistics estimated for PVAR }(2) \text { process } \\
\text { to test the null hypothesis that cointegration rank is at most } \mathrm{r} \text { and }{ }^{\dagger+} \text { denotes the rejection of the } \\
\text { corresponding null at the } 1 \% \text { level. }\end{array}$} \\
\hline
\end{tabular}

The positive long-run relationship between outflows and inflows appears to be the case also for portfolio (eq. 2.2) and FDI (eq. 2.3) flows. For other investment flows, on the other hand, there is a negative relationship (albeit with a relatively low coefficient) between outflows and inflows (eq. 2.4). Better GFC (a decrease in VIX) lead to a decrease in other investment (oinv_of) outflows from EME in the long-run. However, domestic agents tend not to change their net purchases of domestic bonds and equities in the case of a change in GFC as suggested by statistically insignificant 
coefficient of vix in Eq. 2.2. Consistent with the findings of the recent literature suggesting that FDI are more stable (Blanchard et al., 2017; Hoggarth et al., 2016; Eichengreen et al., 2018) than the other components of capital flows and largely determined basically by domestic pull factors (Cerutti et al., 2017) the VIX coefficient is found to be statistically insignificant in the long-run equation (2.3).

The main components of capital inflows adjust to deviations from the long-run equilibrium relationships as suggested by the negative and significant equilibrium correction coefficients. An improvement in GFC (a decrease in VIX) leads to an increase in all types of capital outflows from EME also in the short-run and this impact is substantially larger for the other investment outflows. The short-run relationship between capital inflows and outflows tends to be significantly negative for all the main components, except other investment flows. Consequently, consistent with the postulations of conventional international macroeconomic theory, the behaviours of domestic and foreign investors may be interpreted as not to systematically diverge from the other in the short-run. The asymmetry, suggested by the recent empirical literature, on the other hand, appears to the case in the long-run.

\section{II.2. The Dynamics of Capital Inflows to AE}

For the advanced economies (AE) sample, we consider the following PECM specification:

$$
\Delta \mathrm{CIF}_{\mathrm{it}}=\mathrm{c}_{0}+\alpha_{1} \mathrm{EC}_{\mathrm{it}-1}+\Gamma_{1} \Delta \mathrm{COF}_{\mathrm{it}-1}+\Gamma_{2} \Delta \mathrm{CIF}_{\mathrm{it}-1}+\Gamma_{3} \Delta \mathrm{vix}_{\mathrm{t}-1}+\mathrm{u}_{\mathrm{it}}
$$

where the equilibrium correction term ${ }^{8} \mathrm{EC}$ is $\left(\mathrm{CIF}_{\mathrm{it}}-\mathrm{b}_{1} \mathrm{COF}_{\mathrm{it}}-\mathrm{b}_{2} \mathrm{vix}_{\mathrm{t}}\right)$.

Table 3 presents the PECM results. According to the Johansen-Fisher trace statistics $(\lambda(r))$ there is one cointegration relationship between capital inflows, outflows and vix. An increase in outflows leads to an increase in inflows for the aggregate, FDI and other investment but not for the portfolio flows in the long-run. A

\footnotetext{
${ }^{8}$ Contrasting with the EME sample, our preliminary analysis suggested that, capital inflows are the equilibrium correcting variables for $\mathrm{AE}$. The EC (adjustment) coefficients for the PECM specifications for aggregate, portfolio, FDI and other investment outflows are estimated, respectively, as $0.231(0.05) * *,-0.0009(0.003),-0.466(0.05)^{* *}$ and $-0.010(0.081)$ with standard errors in parentheses and $* *$ denote statistical significance at the $1 \%$ level.
} 
deterioration of global financial conditions leads to an increase in all types of capital inflows to AE except FDI. This may be explained by the capital outflows from EME to $\mathrm{AE}$ are mainly driven by quality/safety concerns during turmoil phases of the international financial cycle. Considering also the results for the EME suggesting an increase in capital outflows in response to an increase in VIX, we may interpret that the safe haven flows to $\mathrm{AE}$ and risk-on capital outflows from EME are intimately connected. Similar to the EME findings, the evolution of FDI tends to be statistically invariant to GFC in AE in the long-run (Eq. 3.3). As already discussed, this finding is consistent with earlier studies including Blanchard and Acalin (2016), Hoggarth et al., (2016), Cerutti et al., (2017) and Eichengreen et al., (2018). The equilibrium correction estimates all strongly suggests that capital inflows (aggregate and components) adjust to deviations from the long-run equilibrium relationships. The adjustment appears to be very fast (almost within the period) for the aggregate (eq. 3.1) and other investment (eq. 3.4) inflows. Consistent with the postulation that they are much stable, the equilibrium correction tends to be relatively slow for FDI inflows (eq. 3.4).

The long-run "twin" behaviour, however, appears not to be the case in the short-run for aggregate capital (eq. 3.1), FDI (eq. 3.3) and other investment (eq. 3.4) flows. For all these, consistent with the conventional wisdom, the behaviours of residents and non-residents tends not to diverge from each other in the short-run. For portfolio flows, on the other hand, the behaviour of residents tends to be not significantly determined by non-residents (eq. 3.2). For all capital flow types, worsening GFC leads domestic residents to decrease their net purchases of foreign assets in the short-run. Consequently, the flight to safety concern, in the case of a financial turbulence may be interpreted as the case in the long-run for AE. 
Table 3. The Dynamics of Capital Inflows to AE

\begin{tabular}{|c|c|c|c|c|}
\hline $\begin{array}{l}\text { Dependent } \\
\text { variable }\end{array}$ & $\Delta c \_$if $_{\text {it }}$ & $\Delta \mathrm{p} \_$if $_{\text {it }}$ & $\Delta$ fdi_if & $\Delta$ oinv_if ${ }_{\text {it }}$ \\
\hline $\begin{array}{l}\text { Capital flow } \\
\text { variable }\end{array}$ & $\begin{array}{c}\text { Aggregate } \\
\text { Capital inflows }\end{array}$ & $\begin{array}{l}\text { Portfolio } \\
\text { inflow }\end{array}$ & FDI inflow & $\begin{array}{l}\text { Other inv. } \\
\text { Inflow }\end{array}$ \\
\hline Equation & $(3.1)$ & $(3.2)$ & (3.3) & $(3.4)$ \\
\hline \multicolumn{5}{|c|}{ Long-run (EC) } \\
\hline & c_ifit & p_if ${ }_{i t}$ & fdi_ifit & oinv_if $f_{\text {it }}$ \\
\hline of $_{\text {it }}$ & $0.625(0.033)^{* *}$ & $-0.041(0.062)$ & $0.880(0.056)^{* *}$ & $1.029(0.046)^{* *}$ \\
\hline $\operatorname{vix}_{t}$ & $0.819(0.167)^{* *}$ & $0.894(0.123)^{* *}$ & $-0.010(0.116)$ & $0.206(0.101)^{* *}$ \\
\hline \multicolumn{5}{|c|}{ Short-run dynamics } \\
\hline $\mathrm{EC}_{\mathrm{t}-1}$ & $-1.194(0.082)^{* *}$ & $-0.539(0.049)^{* *}$ & $-0.220(0.050)^{* *}$ & $-1.132(0.082)^{* *}$ \\
\hline$\Delta \mathrm{if}_{\mathrm{it}-1}$ & $0.131(0.060)^{* *}$ & $-0.129(0.045)^{* *}$ & $-0.452(0.045)^{* *}$ & $0.063 \quad(0.058)$ \\
\hline$\Delta \mathrm{of}_{\mathrm{it}-1}$ & $-0.417(0.057)^{* *}$ & $0.016(0.029)$ & $-0.131(0.042)^{* *}$ & $-0.588(0.071)^{* *}$ \\
\hline$\Delta$ vix $_{\mathrm{t}-1}$ & $-8.411(2.084)^{* *}$ & $-0.868(0.640)$ & $-1.528(0.788)^{*}$ & $-7.010(1.822)^{* *}$ \\
\hline Statistics & $\begin{array}{l}\mathrm{N}=23 \quad \mathrm{NT}=528 \\
\mathrm{R}^{2}=0.46 \\
\mathrm{~F}=150.1 \\
\lambda(0)=103.8^{\dagger \dagger} \\
\lambda(1)=44.2 \\
\lambda(2)=20.3\end{array}$ & $\begin{array}{l}\mathrm{N}=23 \quad \mathrm{NT}=522 \\
\mathrm{R}^{2}=0.32 \\
\mathrm{~F}=80.1 \\
\lambda(0)=99.7^{\dagger \dagger} \\
\lambda(1)=46.6 \\
\lambda(2)=18.7\end{array}$ & $\begin{array}{l}\mathrm{N}=23 \quad \mathrm{NT}=532 \\
\mathrm{R}^{2}=0.36 \\
\mathrm{~F}=100.5 \\
\lambda(0)=102.5^{\dagger} \\
\lambda(1)=37.2 \\
\lambda(2)=19.7\end{array}$ & $\begin{array}{l}\mathrm{N}=23 \quad \mathrm{NT}=551 \\
\mathrm{R}^{2}=0.43 \\
\mathrm{~F}=136.9 \\
\lambda(0)=114.6^{\dagger \dagger} \\
\lambda(1)=51.3 \\
\lambda(2)=24.1\end{array}$ \\
\hline
\end{tabular}

Notes: The values in parentheses are the standard errors. $*$ and $* *$, respectively, denote significance at $5 \%$ and $1 \%$ levels. N and NT are, correspondingly, the numbers of countries and effective number of observations. $\lambda(r)$ are the Johansen-Fisher trace statistics estimated for PVAR(2) process to test the null hypothesis that cointegration rank is at most $r$ and ${ }^{\dagger \dagger}$ denotes the rejection of the corresponding null at the $1 \%$ level. 


\section{CONCLUDING NOTES}

The perfect international financial markets postulation of conventional wisdom suggests that portfolio choices of residents and non-residents do not systematically diverge from each other especially in the long-run. Consequently, such "twin" behaviours of economic agents are expected to lead capital inflows (net purchases of domestic assets by non-residents) and outflows (net purchases of foreign assets by residents) to be negatively correlated and thus may be interpreted as "distant cousins". The recent empirical literature, on the other hand, finds that residents and non-residents behave, indeed, as distant cousins leading capital inflows and outflows to behave as twins. The results of this paper, however, strongly suggest that all these relationships may be different in the long-run than in the short-run.

This paper argues that the integration and cointegration properties of the variables of interest along with the dynamic adjustment mechanisms towards longrun equilibrium should be taken into account in investigating the relationships between capital inflows and outflows. Consequently, the evidence based basically on a panel fixed effect procedures between variables with different orders of integration may better be interpreted with a caution. Our results strongly suggest that, not only the aggregate capital flows but also their main components may behave different in the short-run than in the long-run.

The long-run evolution and the adjustment mechanisms to deviations from the long-run equilibrium relationships are tended to be driven by the behaviours of residents for the EME sample and non-residents for the AE sample. For the EME sample, the equilibrium correction variable is estimated as capital outflows, that is net purchases of foreign assets by residents. The net purchases of domestic assets by foreign residents (capital inflows), on the other hand, adjust to achieve equilibrium for the AE sample. 
Consistent with the findings of the recent empirical literature, we find that there is a strong co-movement between capital inflows and outflows in the long-run 9 The only exceptions are the other investment flows for the EME sample and portfolio flows for the $\mathrm{AE}$ sample. The long-run equilibrium relationships are consistent with the expansion (retrenchment) of financial globalisation (sum of country's international assets and liabilities) during the tranquil (turmoil) periods of global financial conditions (Milesi-Ferretti and Tille, 2011; Forbes and Warnock, 2012; Broner et al., 2013; Rey, 2016).

Contrasting with the long-run evidence, the short-run relations between capital inflows and outflows appear to be significantly negative or insignificant for all the components of capital flows both in AE and EME. Consequently, supporting the conventional wisdom, the "distant cousin" behaviours of residents and nonresidents leading to this "twin" behaviours of capital inflows and outflows, may be interpreted as not to be the case in the short-run.

The state of the global financial cycle proxied by the VIX is found to be an important determinant of capital flows both in EME and AE. A turbulence in international financial markets leads to an increase in capital outflows from EME in the long-run. Consistent to flight to safety concerns, capital inflows to AE increases under such conditions. The short-run behaviours, however, often are not the same. In response to worsening global financial conditions, we observe increases in net purchases of foreign assets (domestic assets) by residents (non-residents) in EME (AE). This is consistent with a stylised fact that, both capital inflows and outflows decrease leading to retrenchment in the case of a global financial turbulence such as the recent global financial crisis.

\footnotetext{
9 Our findings suggesting that gross capital inflows and outflows move in tandem and this is stronger for $\mathrm{AE}$ is in line with the panel bivariate results of Broner et al., (2013). Broner et al., (2013, footnote 11) notes that, their results are robust to inclusion of control variables such as the VIX. The results of this study suggest that this co-movement is, often, the case for the long-run.
} 


\section{REFERENCES}

Avdjiev, S., Hardy, B., Kalemli-Ozcan, S. and Servén, L. (2017). 'Gross capital flows by banks, corporates and sovereigns', NBER Working Paper \# 23116.

Barrot, L.D. and Serven, L. (2018). 'Gross capital flows, common factors, and the global financial cycle', World Bank Policy Research Paper \# 8354.

Blanchard, O. and Acalin, J. (2016). 'What does measured FDI actually measure?', Peterson Institute for International Economics Policy Briefs PB16-17.

Blanchard, O., Ostry, J.D., Ghosh, A.R. and Chamon, M. (2017). 'Are capital inflows expansionary or contractionary? Theory, policy implications and some evidence', IMF Economic Review, 65(3), pp. 563-585.

Broner, F., Alberto M. and Ventura, J. (2010). 'Sovereign risk and secondary markets', American Economic Review, 100 (4), pp. 1523-55.

Broner, F., Didier, T., Erce, A. and Schmukler, S.L. (2013). 'Gross capital flows: Dynamics and crises', Journal of Monetary Economics, 60, pp. 113-133.

Bruno, V. and Shin, H.S. (2015). 'Cross border banking and global liquidity', Review of Economic Studies, 82(2), pp. 535-564.

Cerutti, E., Claessens S. and Rose, A.K. (2017). 'How important is the global financial cycle? Evidence from capital flows', CEPR discussion paper \#12075.

Davis, S.C. and van Wincoop, E. (2017). 'Globalization and the increasing correlation between capital inflows and outflows', NBER Working Paper \# 23671.

Eichengreen, B., Gupta, P. and Masetti, O. (2018). 'Are capital flows fickle? Increasingly? And does the answer still depend on type?', Asian Economic Papers, 17(1), pp. 22-41.

Erdem, F.P. and Özmen, E. (2015). 'Exchange rate regimes and business cycles: An empirical investigation', Open Economies Review, 26, pp. 1041-1058.

Fisher, R.A. (1932). 'Statistical Methods for Research Workers', Edinburgh: Oliver \& Boyd.

Forbes, K.J. and Warnock, F.E. (2012). 'Capital flow waves: Surges, stops, flight, and retrenchment', Journal of International Economics, 88(2), pp. 235-251.

Gonzalez-Rozada, M. and Levy-Yeyati, E. (2008). 'Global factors and emerging market spreads', The Economic Journal, 118 (533), pp. 1917-1936.

Groen, J.J. and Kleibergen, F. (2003). 'Likelihood-based cointegration analysis in panels of vector error-correction models', Journal of Business and Economic Statistics, 21, pp. 295-318.

Hoggarth, G., Jung, C. and Reinhardt, D. (2016). 'Capital inflows - The good, the bad and the bubbly', Bank of England Financial Stability Paper \# 40.

Johansen, S. (1995). 'Likelihood-based inference in cointegrated vector autoregressive models', Oxford: Oxford University Press.

Kose, A., Otrok, C. and Prasad, E.S. (2012). 'Global business cycles: Convergence or decoupling?', International Economic Review, 87, pp. 178-90.

Larsson, R., Lyhagen, J. and Löthgren, M. (2001). 'Likelihood-based cointegration tests in heterogeneous panels', The Econometrics Journal, 4(1), pp. 109-142. 
Levin, A., Lin, C.F. and Chu, C.S.J. (2002). 'Unit root tests in panel data: asymptotic and finite-sample properties', Journal of Econometrics, 108(1), pp. 1-24.

Maddala, G.S. and Kim, I.M. (1998). 'Unit roots, cointegration, and structural change', Cambridge University Press.

Milesi-Ferretti, G.M. and Tille, C. (2011). 'The great retrenchment: International capital flows during the global financial crisis', Economic Policy, 26(66), pp. 285-342.

Montiel, P.J. (2014). 'Capital flows: Issues and policies', Open Economies Review, 25, pp. 595-633.

Obstfeld, M., Ostry, J.D. and Qureshi, M.S. (2017). 'A tie that binds: Revisiting the trilemma in emerging market economies', IMF Working Paper \# WP/17/130.

Örsal, D.D.K. and Droge, B. (2014). 'Panel cointegration testing in the presence of a time trend', Computational Statistics \& Data Analysis, 76, pp. 377-390.

Özatay, F., Özmen, E. and Sahinbeyoglu, G. (2009). 'Emerging market sovereign spreads, global financial conditions and U.S. macroeconomic news', Economic Modelling, 26, pp. 526-531.

Rey, H. (2015). 'Dilemma not trilemma: The global financial cycle and monetary policy independence', NBER Working Paper \# 21162.

Rey, H. (2016). 'International channels of transmission of monetary policy and the Mundellian trilemma', IMF Economic Review, 64(1), pp. 6-35.

Tille, C. and van Wincoop, E. (2010). 'International capital flows', Journal of International Economics, 80(2), pp. 157-175.

Tille, C. and van Wincoop, E. (2014). 'International capital flows under dispersed private information', Journal of International Economics, 93(1), pp. 31-49. 